\title{
COMPOSITION AND PROPERTIES OF HUMAN CERVICAL MUCUS. I. ELECTROPHORETIC SEPARATION AND IDENTIFICATION OF PROTEINS *
}

\author{
By KAMRAN MOGHISSI, OTTO W. NEUHAUS AND CHARLES S. STEVENSON \\ (From the Departments of Physiological Chemistry, Obstetrics and Gynecology, and Anatomy, \\ Wayne State University College of Medicine, Detroit, Mich.)
}

(Submitted for publication March 7, 1960 ; accepted May 13, 1960)

The importance of cervical mucus in female infertility is generally recognized (1). Clinical characteristics of human cervical mucus have been the subject of many studies in recent years. However, very little is known about the chemical composition or the biological significance of this epithelial secretion.

Cervical mucus normally contains from 92 to 94 per cent water in the pre- and post-ovulatory phases, while in midcycle the water content rises to 98 per cent (2). The primary constituent is believed to be a mucopolysaccharide composed of galactose and hexosamine as well as some fucose and sialic acid $(3,4)$. Recent experiments with $\mathrm{S}^{35}$-labeled sulfate have shown the presence of sulfate in the cervical mucus of rabbit and guinea pigs $(5,6)$. Both human and rabbit cervical gland and secretions react metachromatically with toluidine blue (7-9), indicating the presence of an acid mucopolysaccharide. The absence of uronic acid and the lack of effect by testicular hyaluronidase on cervical mucus eliminates the probability that this mucopolysaccharide is either hyaluronic acid or one of the chondroitin sulfates. If the sulfate groups are bound to mucopolysaccharides, which has not been proven, it seems likely that they are from keratosulfate, a sulfated polysaccharide composed of galactose and glucosamine $(9,10)$.

The presence of proteins in the cervical mucus is generally conceded $(3,4,10)$. Pommerenke found that cervical mucus gave a positive biuret test and positive reactions for tryptophan, tyrosine and cysteine (2). Werner determined the total nitrogen content of the pooled cervical mucus to be 12.1 per cent (4). This, in part, represented protein(s) which could be digested by trypsin, and

* This study was supported by Grants A-3430 and RG-7031(a) from the National Institutes of Health, Bethesda, Md. which yielded 15 amino acids upon acid hydrolysis. Shettles, Dische and Osnos have suggested the total protein content to be about 1 per cent (3), while Werner reported between 0.5 and 3 per cent (10).

Spencer, Sunseri and Sunseri (11), using paper electrophoresis, found two main bands in cervical mucus of normal and pregnant women, a nonmigratory band and a diffuse one. The nonmigratory band stained strongly with periodic acid-Schiff reagent (PAS), was strongly metachromatic, and positive to the Feulgen reaction. The diffuse band was PAS-positive, faintly metachromatic, and negative to the Feulgen reaction. No areas identifiable with the usual serum peaks were recognized as normal components of the cervical mucus. As a matter of fact, it was suggested that the appearance of albumin in cervical mucus would indicate the existence of some pathological state in the genital tract. Electrophoretic studies using a paper medium are open to serious question because of complications arising from the highly viscous character of the sample.

The purpose of the present study is to show the presence of albumin and other electrophoretically identifiable protein areas in the normal cervical mucus using the technique of agar gel electrophoresis.

\section{METHODS}

Collection of specimens. Samples of cervical mucus were obtained from selected patients attending the gynecological outpatient clinic at Detroit Receiving Hospital. Great care was taken to exclude all cases of menstrual disorders, vaginitis, gross cervicitis, and other pelvic abnormalities. Table I shows the clinical data for 21 cases used in this study ranging in age from 16 to 36 . Eighteen women had had between 1 and 10 pregnancies, 2 women were unmarried, and 1 was newly married. The day of the cycle on which the specimen was taken was determined by questioning the patient and by correlating this date with the physical appearance of the cervical secretion, its $\mathrm{pH}$, spinnbarkeit (12), and extent of arbor- 
ization (13). Cervical mucus was aspirated from the cervical canal, after gently cleaning the portio and external os with a cotton ball. All samples were refrigerated and examined within 24 hours. Specimens tinged with blood were discarded.

Electrophoretic separation. An attempt was made to separate the proteins of cervical mucus by electrophoresis on paper. In agreement with Spencer and co-workers (11), only a nonmigrating and a diffuse band were obtained, as shown in Figure 1. These authors considered such patterns typical for normal cervical mucus. Previous experience in our laboratory with synovial fluid often showed poor separations of proteins unless the samples were first treated with hyaluronidase to depolymerize the hyaluronic acid (14). Therefore, it was considered possible that the mucopolysaccharide of cervical mucus in some way might have hindered the electrophoretic separation of the proteins when a paper supporting medium was used. In a preliminary test the gelatinous character of a sample of cervical mucus was markedly reduced prior to paper electrophoresis by treating the sample with a small amount of $0.1 \mathrm{~N} \mathrm{NaOH}$. However, this did not change the electrophoretic pattern.

Electrophoresis in an agar medium was considered to be the most likely technique for separating proteins of the highly viscous samples of cervical mucus. The method of Zak, Volini, Briski and Williams was used in

TABLE I

Clinical dato

\begin{tabular}{|c|c|c|c|c|c|c|}
\hline Case & $\begin{array}{l}\text { Hospital } \\
\text { serial } \\
\text { no. }\end{array}$ & Age & Cycle & Gravida & Para & Remarks \\
\hline $\begin{array}{l}1 \\
2 \\
3 \\
4 \\
5\end{array}$ & $\begin{array}{r}301529 \\
204180 \\
37890 \\
245688 \\
77701\end{array}$ & $\begin{array}{l}26 \\
16 \\
24 \\
35 \\
22\end{array}$ & $\begin{array}{l}3 / 28 \\
4 / 28 \\
5 / 28 \\
3 / 27 \\
4 / 28\end{array}$ & $\begin{array}{l}\text { I } \\
0 \\
\text { II } \\
\text { III } \\
\text { III }\end{array}$ & $\begin{array}{l}\text { I } \\
0 \\
\text { II } \\
\text { II } \\
\text { III }\end{array}$ & Unmarried \\
\hline 6 & 280845 & 27 & $5 / 28$ & II & I & $\begin{array}{l}\text { Salpingectomy } \\
\text { for ectopic } \\
\text { pregnancy }\end{array}$ \\
\hline 7 & 18743 & 36 & $4 / 26$ & VIII & VI & $\begin{array}{l}\text { Salpingectomy } \\
\text { for ectopic } \\
\text { pregnancy }\end{array}$ \\
\hline $\begin{array}{r}8 \\
9 \\
10\end{array}$ & $\begin{array}{r}67438 \\
316767 \\
71233\end{array}$ & $\begin{array}{l}31 \\
23 \\
35\end{array}$ & $\begin{array}{l}3 / 28 \\
5 / 28 \\
3 / 28\end{array}$ & $\begin{array}{l}\text { X } \\
\text { II } \\
\text { VII }\end{array}$ & $\begin{array}{l}\text { VI } \\
\text { II } \\
\text { VI }\end{array}$ & \\
\hline $\begin{array}{l}11 \\
12 \\
13 \\
14 \\
15\end{array}$ & $\begin{array}{r}2283 \\
314959 \\
136310 \\
682998 \\
310619\end{array}$ & $\begin{array}{l}31 \\
17 \\
17 \\
19 \\
21\end{array}$ & $\begin{array}{l}7 / 28 \\
4 / 30 \\
4 / 28 \\
5 / 28 \\
5 / 26\end{array}$ & $\begin{array}{l}\text { V } \\
\text { I } \\
0 \\
\text { II } \\
\text { I }\end{array}$ & $\begin{array}{l}\text { III } \\
\text { I } \\
0 \\
\text { II } \\
\text { I }\end{array}$ & Unmarried \\
\hline $\begin{array}{l}16 \\
17 \\
18 \\
19 \\
20 \\
21\end{array}$ & $\begin{array}{l}304614 \\
315191 \\
118825 \\
101264 \\
317666 \\
145628\end{array}$ & $\begin{array}{l}21 \\
24 \\
27 \\
28 \\
19 \\
21\end{array}$ & $\begin{array}{l}5 / 30 \\
3 / 28 \\
3 / 28 \\
3 / 35 \\
4 / 30 \\
1 / 35\end{array}$ & $\begin{array}{l}\text { III } \\
\text { II } \\
0 \\
\text { V } \\
\text { I } \\
\text { II }\end{array}$ & $\begin{array}{l}\text { III } \\
\text { II } \\
0 \\
\text { IV } \\
\text { I } \\
\text { II }\end{array}$ & $\begin{array}{l}\text { Mucus very poor } \\
\text { in protein* }\end{array}$ \\
\hline
\end{tabular}

* Protein content was too small to allow electrophoretic study.

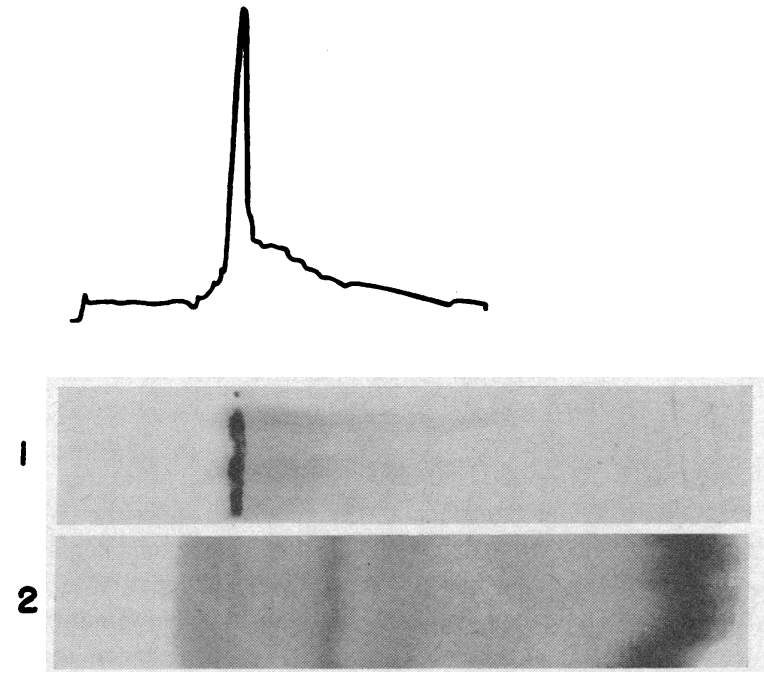

Fig. 1. AN ATtEMPTED ELECTROPHORETIC SEPARATION OF CERVICAL MUCUS PROTEINS ON WhatMan NO. 3 MM PAPER (SPINCo APPARATUs). Strip 1, a sample of normal cervical mucus showing no migration of proteins; Strip 2, concurrently run sample of human serum showing usual electrophoretic migration of proteins.

which only enough agar was added to the buffer medium to act as a thickening agent (15). Preliminary experi-. ments showed that good separations of the proteins of cervical mucus could be obtained by this technique.

The apparatus used for this study was identical with that described by Zak and associates (15). A watertight compartment for holding the agar-buffer medium was made by cementing ${ }^{1}$ glass rods ( $2 \mathrm{~mm}$ in diameter) to the four edges of a $3.5 \times 4$ inch lantern slide coverglass which had previously been covered by a sheet of vegetable parchment paper. ${ }^{2}$ About $15 \mathrm{ml}$ of a hot agar-buffer solution, prepared by dissolving $250 \mathrm{mg}$ of Bacto-Difco (certified pure) agar in $100 \mathrm{ml}$ of boiling $0.05 \mu$ veronal buffer, $\mathrm{pH}$ 8.6, was transferred to the glass basin. The plate was raised to the same level as the buffer in the electrode boxes by means of a micro lab-jack. Paper wicks ${ }^{3}$ were used to connect the agar medium with the buffer boxes. The agar-buffer solution was then allowed to gel. The samples were applied by immersing small strips $(0.5 \times 8 \mathrm{~mm})$ of Whatman no. $3 \mathrm{MM}$ filter paper in the cervical mucus and by placing these on the agar gel about 1.25 inches from the cathodic end. A sample of human serum, prestained with bromphenol blue, was similarly placed on the agar as a guide for estimating the length of migration and also for comparing the position of the various fractions in the mucus specimen. After electrophoresis for 45 or 50 minutes at $250 \mathrm{v}$ (40 to 60

\footnotetext{
1 Label varnish, Cenco no. 11380.

2 No. 72 vegetable parchment powder paper available through the Upjohn Co.

${ }^{3}$ Schleicher and Schuell filter paper, grade no. 900 cut into $3.5 \times 4$ inch rectangles.
} 
ma), the agar plate was dried under an infrared lamp. The parchment paper, now having on its surface the dried, separated sample, was detached from the glass plate and stained for 20 to 30 minutes in 0.1 per cent bromphenol blue solution. Excess dye was removed by successive rinsing in a 5 per cent solution of acetic acid until the background became white. The stained paper was air dried and then exposed to ammonia fumes to intensify the color.

For the quantitative determination of the protein components, the individual electrophoretic bands were cut from the pattern and the bromphenol blue was eluted with a 2 per cent solution of sodium carbonate in 50 per cent methanol. After 30 minutes of occasional shaking the solutions were decanted and their optical densities were measured at $590 \mathrm{~m} \mu$ using a Coleman spectrophotometer.

Immunological reactions. The Ouchterlony double diffusion technique as modified by Wilson and Goodman was used (16). This method is considered to be more sensitive than the one using the typical five basin Ouchterlony plate (17). The modified plates ( $3 \%$ inches in diameter) were made of $1 / 4$ inch Lucite and contained two " $T$ " shaped wells as shown in Figure 2A. These wells were filled with a 0.75 per cent solution of agar in a 13 per cent $\mathrm{NaCl}$ solution. After the gel had formed, the agar was removed from the three $10 \times 10 \mathrm{~mm}$ basins, nos. 1,2 and 3 , thereby leaving the agar block no. 4 (Figure 2B). Wells 1 and 3 were reserved for the sample to be tested - while no. 2 was used for the appropriate chicken antiserum. The precipitin reaction occurred in the agar block

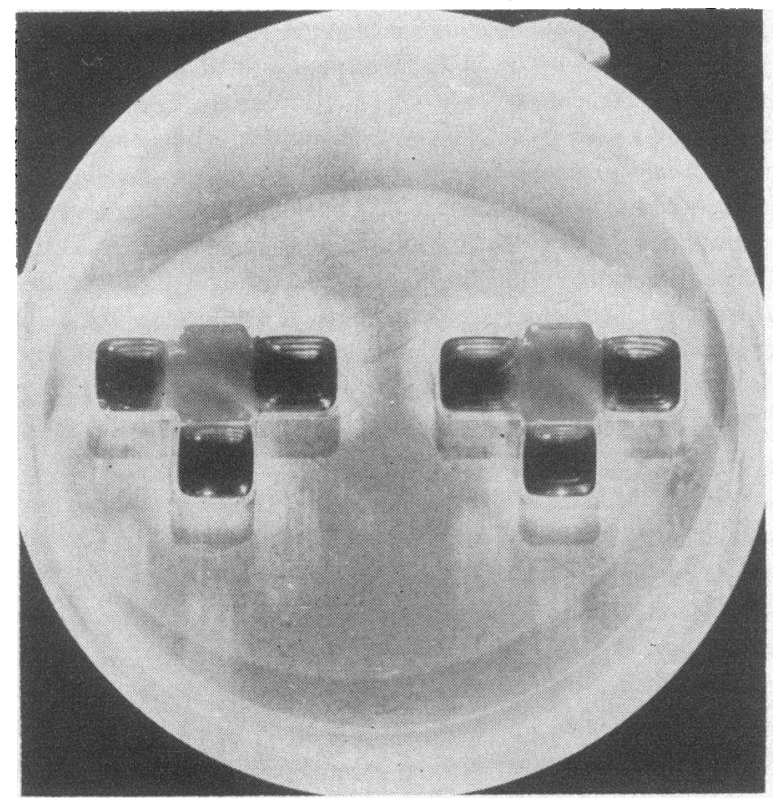

A as a crescent extending from well 1 to well 3 as shown in Figure 2B.

In all experiments chicken antiserum (18) specific for human albumin and $\gamma$-globulins was used to develop the albumin and $\gamma$-globulins of the cervical mucus.

\section{RESULTS AND DISCUSSION}

The total protein of cervical mucus, determined on a pooled sample (10 cases in different phases of the menstrual cycle) with a biuret method (19), was found to be 1.1 per cent. This value confirmed that of Shettles and associates (3). It would have been desirable to determine the total proteins in individual samples. However, this was not feasible because of difficulties experienced in the quantitative sampling of the small amounts of each specimen available and because of the lack of an adequate micromethod.

Electrophoresis on agar-gel invariably resulted in a separation of proteins into four fractions (Figure 3). These were: $a$ ) a compact band migrating similarly to that of serum albumin; $b$ ) a diffuse band between the origin and the albumin zone; c) a "nonmigrating" fraction which remained at the origin and on the strip of filter paper used to apply the sample; and $d$ ) a band moving toward

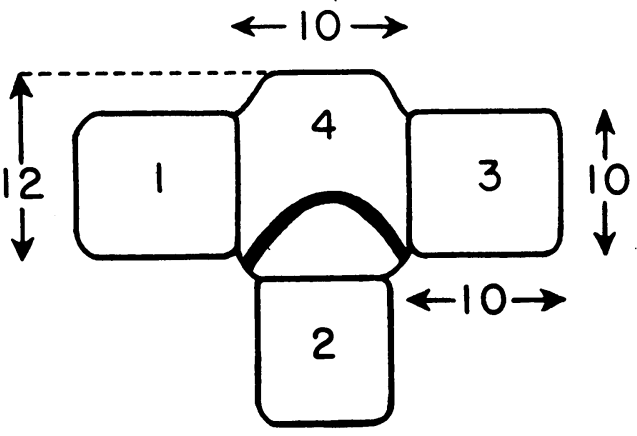

B

Fig. 2. A. Modified Ouchterlony plate of Wilson and Goodman $(16,17)$. B. Diagram showing precipitin REACTION IN AGAR BLOCK No. 4. Wells 1 and 3 were used for samples while 2 was reserved for antiserum. Dimensions in the diagram are given in millimeters. 


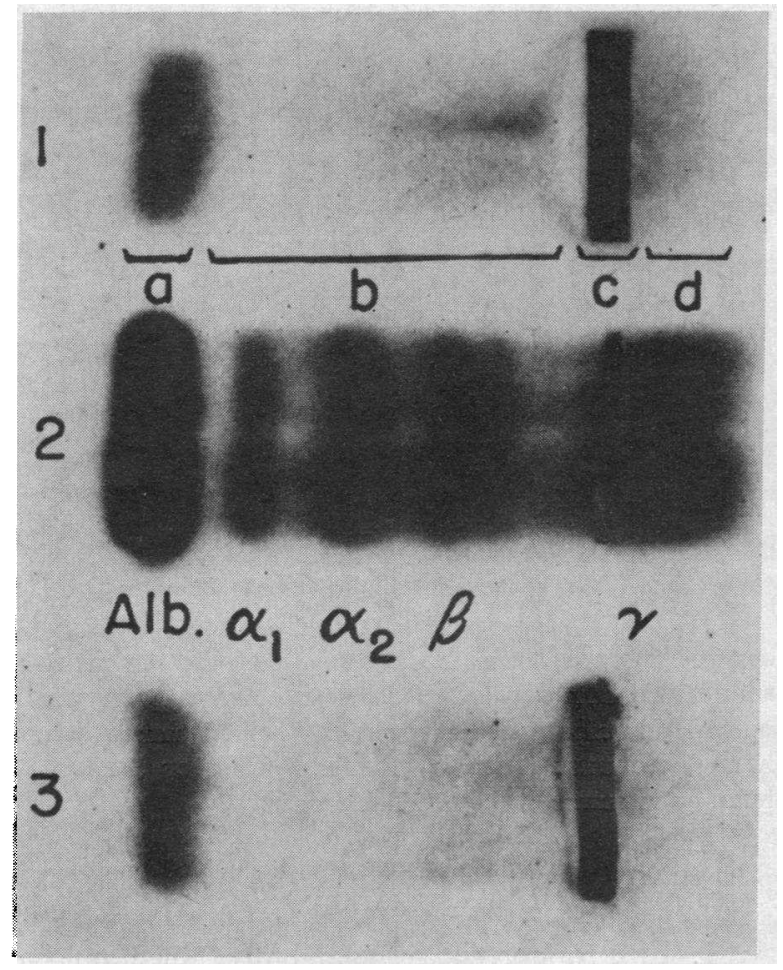

Fig. 3. THE ELECTROPHORETIC SEPARATION OF PROTEINS OF CERVICAL MUCUS IN AN AGAR GEL MEDIUM. 1 and 3 $=$ cervical mucus ; $2=$ normal human serum.

the cathode and resembling $\gamma$-globulin. In some cases a fairly well defined band was observed similar to that of $\beta$-globulin.

Several samples were separated electrophoretically on a Mylar film in place of the usual parchment paper. After drying, these runs were stained by a PAS technique (20). All fractions except the albumin reacted positively. The nonmigrating portion exhibited the most intense reaction for carbohydrate suggesting that the mucopolysaccharide component did not migrate under the conditions of these experiments.

To determine the quantitative distribution of the protein, the electropherograms were divided into three areas: fraction a (albumin), combined fractions $\mathrm{b}$ and $\mathrm{d}$ (globulins), and fraction $\mathrm{c}$ (nonmigrating). The relative distribution of these components is shown in Table II. The 20 cases in this series were subdivided into the usual three periods : postmenstrual, the period dating from the completion of menstruation through the tenth day of the cycle; midcycle, from the eleventh through the eighteenth day of the cycle; and premenstrual, from the nineteenth day of the cycle to the onset of menses. The average percentage of each fraction was calculated for each period as well as for the complete cycle. The amount of albumin was about 21 per cent of the total proteins, while the total globulin fraction was 36 per cent, and the nonmigrating portion averaged 43 per cent. The data are suggestive of a cyclical change in the proportion of the proteins, with albumin and globulins tending to be somewhat reduced during midcycle. However, these variations are not statistically significant.

The identification of the protein components of cervical mucus cannot be based only on electrophoretic mobility. The presence of albumin and $\gamma$-globulin fractions was confirmed by an immunological reaction using the modified Ouchterlony plate of Wilson and Goodman $(16,17)$. The albumin and $\gamma$-globulin fractions of cervical mucus

TABLE II

Relative percentage of electrophoretically separated proteins from the cervical mucus

\begin{tabular}{|c|c|c|c|c|}
\hline \multirow[b]{2}{*}{ Case } & \multirow{2}{*}{$\begin{array}{l}\text { Day of } \\
\text { cycle* }\end{array}$} & \multicolumn{3}{|c|}{ Percentage of fractions } \\
\hline & & Albumin & Globulin & Nonmigrating \\
\hline & \multicolumn{4}{|c|}{ Postmenstrual } \\
\hline $\begin{array}{c}1 \\
2 \\
3 \\
4 \\
5 \\
\text { Average }\end{array}$ & $\begin{array}{l}4 \\
6 \\
7 \\
8 \\
9\end{array}$ & $\begin{array}{l}14.6 \\
28.0 \\
28.2 \\
16.1 \\
18.5 \\
21.1\end{array}$ & $\begin{array}{l}35.6 \\
46.6 \\
35.6 \\
51.0 \\
54.7 \\
44.6\end{array}$ & $\begin{array}{l}49.8 \\
25.4 \\
36.2 \\
32.9 \\
26.8 \\
34.2\end{array}$ \\
\hline & \multicolumn{4}{|c|}{ Midcycle } \\
\hline $\begin{array}{c}6 \\
7 \\
8 \\
9 \\
10 \\
11 \\
\text { Average }\end{array}$ & $\begin{array}{l}12 \\
13 \\
13 \\
14 \\
15 \\
15\end{array}$ & $\begin{array}{r}5.0 \\
12.1 \\
5.2 \\
44.1 \\
12.6 \\
22.5 \\
16.9\end{array}$ & $\begin{array}{l}20.5 \\
30.5 \\
20.3 \\
27.6 \\
46.7 \\
36.2 \\
30.3\end{array}$ & $\begin{array}{l}74.5 \\
57.5 \\
74.4 \\
28.3 \\
40.7 \\
41.2 \\
52.8\end{array}$ \\
\hline & \multicolumn{4}{|c|}{ Premenstrual } \\
\hline $\begin{array}{c}12 \\
13 \\
14 \\
15 \\
16 \\
17 \\
18 \\
19 \\
20 \\
\text { Average }\end{array}$ & $\begin{array}{l}19 \\
20 \\
21 \\
21 \\
23 \\
24 \\
25 \\
28 \\
30\end{array}$ & $\begin{array}{l}25.3 \\
25.5 \\
10.3 \\
20.9 \\
12.2 \\
32.5 \\
14.9 \\
32.7 \\
37.9 \\
23.6\end{array}$ & $\begin{array}{l}36.8 \\
30.7 \\
29.4 \\
37.2 \\
23.7 \\
50.0 \\
23.4 \\
38.9 \\
35.7 \\
34.0\end{array}$ & $\begin{array}{l}37.9 \\
43.8 \\
60.3 \\
41.9 \\
64.0 \\
17.5 \\
61.7 \\
28.6 \\
26.4 \\
42.5\end{array}$ \\
\hline \multicolumn{2}{|c|}{$\begin{array}{l}\text { Total average } \\
\text { for the cycle }\end{array}$} & $20.7 \pm 10.7$ & $35.6 \pm 10.2$ & $43.5 \pm 16.5$ \\
\hline
\end{tabular}

* Day of cycle on which the sample was collected. 


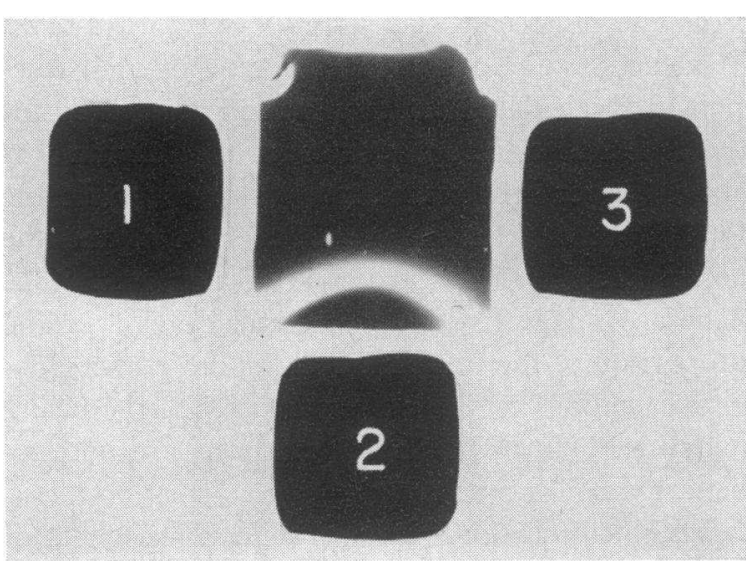

A

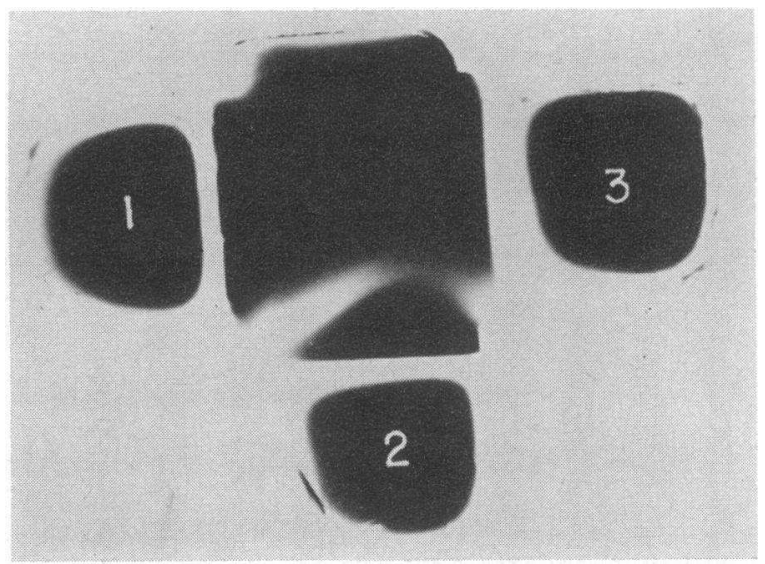

B

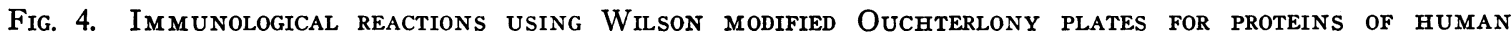
CERVICAL MUCUS. A. REACTIONS OF IDENTITY USING ELECTROPHORETICALLY SEPARATED ALbUMIN AFTER A DIFFUSION TIME of 2 DAYS. $1=$ Albumin from cervical mucus; $2=$ immune anti-albumin antiserum; $3=$ pooled human serum.

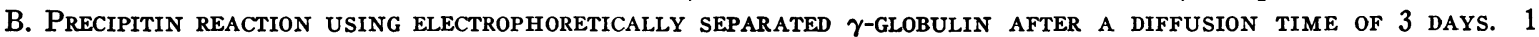
$=\gamma$-Globulin from cervical mucus; $2=$ immune anti- $\gamma$-globulin antiserum; $3=$ pooled human serum.

were first separated electrophoretically. Then the agar plate was frozen and the albumin and $\gamma$ globulin zones were cut out of the electropherogram using a concurrently run prestained sample of human serum to locate these regions. Corresponding bands from several separations were pooled. The $\gamma$-globulin mixture prepared in this manner was concentrated by dialysis against a 20 per cent solution of polyvinylpyrrolidone before use. Electrophoretically separated albumin and $\gamma$-globulins from cervical mucus and pooled human serum were tested, respectively, against immune chicken antihuman sera, specific for albumin and $\gamma$-globulins (18). In all cases a precipitin reaction developed within 72 hours (Figure 4).

The identification of other electrophoretically separated fractions of cervical mucus, namely, those associated with the alpha and beta regions, was not feasible with this technique. It appears, contrary to the opinion of some investigators, that cervical mucus normally contains both albumin and $\gamma$-globulin, which are immunologically identical with those of human serum. The nonmigrating and strongly PAS-positive protein fraction of the mucus may be associated with the mucopolysaccharides which are known to be present in cervical secretion. The absence of electrophoretic mobility may have been the result of adsorption to the filter paper.

\section{SUM MARY}

1. Electrophoresis in agar-buffer medium has been found to be a suitable technique for the study of the proteins of cervical mucus.

2. Albumin and $\gamma$-globulin were shown to be normally present in the cervical secretion of 20 women during various phases of the menstrual cycle. These proteins were identified by immunological techniques.

3. The total protein content of the pooled mucus was found to be about 1 per cent.

4. On the average, there were about 21 per cent albumin, 36 per cent globulins, and 43 per cent of a nonmigrating component in the cervical mucus. The latter fraction was probably associated with the mucopolysaccharides.

5. All of the electrophoretically separated proteins except albumin gave a positive periodic acidSchiff reaction.

\section{ACKNOWLEDGMENTS}

The kind and generous cooperation of Dr. Bennie Zak in assisting us with the electrophoretic studies is greatly appreciated. We wish to express our thanks also to Dr. Morris Goodman and his staff for their help in the immunological investigations and for supplying the necessary materials.

\section{REFERENCES}

1. Stevenson, C. S. Cervical mucus in infertile women. Fertil. and Steril. 1958, 9, 407. 
2. Pommerenke, W. T. Cyclic changes in the physical and chemical properties of cervical mucus. Amer. J. Obstet. Gynec. 1946, 52, 1023.

3. Shettles, L. B., Dische, Z., and Osnos, M. Neutral mucopolysaccharide of the human cervical mucus. J. biol. Chem. 1951, 192, 589.

4. Werner, I. Studies on glycoproteins from mucous epithelium and epithelial secretions. Acta Soc. Med. upsalien. 1953, 58, 1.

5. Moricard, R., Gothie, S., and Belaisch, J. Problème de la fixation du ${ }^{25} \mathrm{~S}$ de la sécrétion cervicale provoquée par les oestrogènes et précédant normalement la fécondation. J. Physiol. (Paris) 1957, 49, 320.

6. Zachariae, F. Autoradiographic $\left({ }^{25} \mathrm{~S}\right)$ and histochemical studies of sulphomucopolysaccharides in the rabbit uterus, oviduct and vagina. Acta endocr. (Kbh.) 1958, 29, 118.

7. Sylvén, B. True and false metachromatic staining reactions of myelin and "epithelial mucus." Nord. med. Ark. 1945, 25, 405.

8. Wislocki, G. B., Bunting, H., and Dempsey, E. W. The chemical histology of the human uterine cervix with supplementary notes on the endometrium in Menstruation and its Disorders, E. T. Engle, Ed. Springfield, Ill., Charles C Thomas, 1950, p. 23.

9. Zachariae, F. The acid mucopolysaccharide of the cervical mucus. Acta obstet. gynec. scand. 1959, 38, suppl. $1,86$.

10. Werner, I. The chemistry of cervical mucus. Acta obstet. gynec. scand. 1959, 38, suppl. 1, 39.

11. Spencer, B., Sunseri, L. Z., and Sunseri, S. G. Electrophoretic examination of human cervical mucus from normal, pregnant and carcinomatous patients. Clin. chim. Acta 1957, 2, 485.
12. Cohn, M. R., Stein, I. F., Jr., and Kaye, B. M. Spinnbarkeit: A characteristic of cervical mucus. Significance at ovulation time. Fertil. and Steril. 1952, 3, 201.

13. Zondek, B. Cervical mucus arborization as an aid in diagnosis in Progress in Gynecology, J. V. Meigs and S. H. Sturgis, Eds. New York, Grune and Stratton, 1957, vol. III, p. 86.

14. Neuhaus, O. W., and Letzring, M. Hexosaminecontaining glycoproteins of normal bovine synovial fluid. J. biol. Chem. 1958, 232, 177.

15. Zak, B., Volini, F., Briski, J., and Williams, L. A. Combined agar gel-paper electrophoresis. Amer. J. clin. Path. 1960, 33, 75.

16. Wilson, M. W., and Goodman, M. In preparation.

17. Goodman, M. The species specificity of proteins as observed in the Wilson comparative analyses plate. Amer. Naturalist 1960, 94, 184.

18. Goodman, M., Ramsey, D. S., Simpson, W. L., Remp, D. G., Basinski, D. H., and Brennan, M. J. The use of chicken antiserum for the rapid determination of plasma protein components. I. Assay of human serum albumin and gamma globulin. J. Lab. clin. Med. 1957, 49, 151.

19. Wolfson, W. Q., Cohn, C., Calvary, E., and Ichiba, F. Studies in serum proteins. V. A rapid procedure for the estimation of total protein, true albumin, total globulin, alpha globulin, beta globulin and gamma globulin in $1.0 \mathrm{ml}$. of serum. Amer. J. clin. Path. 1948, 18, 723.

20. Uriel, J., and Grabar, P. Emploi de colorants dans l'analyse électrophorétique et immunoélectrophorétique en milieu gélifié. Ann. Inst. Pasteur Lille 1956, 90, 427. 